\title{
God's Chisel in the Hands of the Carver: An Esoteric View of Joseph Alufa Igbinovia
}

\author{
Daniel Omoruan ${ }^{1}$ \\ Festus Osarumwense Uzzi, $\mathbf{P h D}^{2}$ \\ ${ }^{1,2}$ Department of Theatre and Media Arts, Ambrose Alli University, Ekpoma, Nigeria \\ Corresponding Author: Festus Osarumwense Uzzi, Email: uzzi.festus@oouagoiwoye.edu.ng
}

\begin{abstract} speech making, painting, molding, carving and poetry to communicate messages to the audience, which is the hallmark of African art. Keywords: Carving, esoteric, woodcraft, Idia mask, visual arts

\section{Introduction}

Carving is an aspect of the visual art. It involves the interaction of the mind, eye and hand in shaping, modeling and remodeling of wood and other physical substances to produce a desired image or form. The carver like a music maker relies on intuition or inspiration as well as on the supernatural as a source for
\end{abstract}

The idea of the supernatural influence in the acts of humans in the past and present is indisputable. It is not in contention that beside God, there are divinities, which he created to support humans in their odyssey on earth. The supreme God, the divinities and spirits make up the ethereal world and in their various projections exercise some influences in the life and careers of their chosen persons or devotees. Religion and creativity are two major aspects that the supernatural influence has been popularly expressed. Creativity is not limited to the league of the 'creative artistes' in spite of the fact that the people commonly ascribe creativity to the practice of the theatre, literature and fine arts. Architecture, fashion design, interior decoration, carpentry, culinary and a number of other professional practices fall within the domain of creative endeavors. What is unique about the creative artiste is that he or she has a more robust influence of the supernatural or muse. Therefore, the objective of this study is to examine how the artist is inspired by the supernatural in the process of his or her artistry and how he or she responds to this extra-terrestrial impartation in the creation of his or her works. In particular, Joseph Alufa Igbinovia, an African carver, has been discussed and analyzed from the perspective of esoterism. The theoretical framework that has been adopted in this study is artistic communication theory (ACT), which is a means by which artists communicate their messages to the society. Artistic communication refers to a method of communication that uses a wide range of artistic endeavors such as music, drama, dance,

Article History:

Submitted 29 September 2021

Revised 26 December 2021

Accepted 13 January 2022

\section{Copyright Information:}

Copyright 2022 ( ) The Author(s). The publisher may reuse published articles with prior permission of the concerned author(s). The work is licensed under a Creative Commons Attibution 4.0 International License (CC BY 4.0).

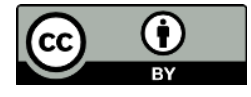

Volume 4, No. 1, February 2022 [pp. 44-52]

SCHOLARS: Journal of Arts \& Humanities 
the construction or creation of his forms/images. Sometimes, both the music maker and the carver rely on supernatural impartation to create their products, but while the product of the music maker is intangible, that of the carver is tangible (Osakue and Omoruan 31). Joseph Alufa Igbinovia is one of such carvers that has relied on both physical and spiritual sources in the creation of their varied art works. It is based on the mixed nature of the carver that Sam Akpabot views that trees located near pathways are most suitable for the production of drums because their proximity to human voices has been used in shaping their growth from the beginning and this can be harnessed and resonated by a skillful and inspired drum carver (86). In this study, the professional career of Joseph Alufa Igbinovia has been considered from the point of view of his birth and works as acts of destiny. He is also considered from the perspective of the political and art history of Nigeria as the carver who reproduced the replica of the original Queen Idia mask of the Benin kingdom, which was one of the artifacts of great value taken away by the British colonial imperialist, as well as an artist whose artistic prowess bestrode the African and black world for his role in the 2nd Black and African Festival of Arts and Culture (FESTAC 77) held in Lagos, Nigeria, in 1977; an event that emphasized the cultural and spiritual consciousness of the black world. The expertise which Igbinovia displayed in the reproduction of Queen Idia mask further emphasized the artistry, which the carvers in the ancient Benin kingdom exhibited that accounted for the presence of antiques of great value in the kingdom. It was one of the reasons that ocassioned the British invasion, conquest and looting of the kingdom's artifacts in 1897 that brought the people and their art works to global limelight.

\section{Methodology}

Methodology refers to the methods that the researchers use to gather materials/information that they need in writing their papers, theses or dissertations or to address an empirical truth. The methodology used in this work is visual, literary and key informant's interview (KII) and personal observation. The research is qualitative in perspective. The artists are known to derive an inspiration from the muse, which in the ancient Greece is the inspirational goddess of literature and the arts (Brockett 4) and highly talented or gifted artists are imbued with esoteric instincts and in this capacity have close and inexplicable affinity to a patron god or deity that inspires them. Wole Soyinka's patron god is Ogun (Moore 4) and Majek Fashek's is Olokun or the river goddess (Osakue and Omoruan 40). It is within the capacity of the influence of the supernatural on selected artists that Igbinovia's professional oeuvre under his patron god Orunmila has been examined in this study. These are deities in the African pantheon that can influence the career and life circumstances of their chosen devotees. The researchers have relied on the above methods to gain deep insight into the nature, life style, works and worldview of the artist Igbinovia while further relying on the ambience of his residence, workshop and worship center all rolled into one to understand and appreciate his personality and works.

\section{Joseph Alufa Igbinovia: Childhood and Parenting}

Igbinovia was born on 1 January 1949. His father Igbinovia Obayagbona

Noweko was the son of Obayagbona who resided at the Lagos street, located close to the palace of Chief Ogbeideyo Obaseki's residence, the regent that ruled Benin kingdom at the dethronement and banishment of Oba Ovonramwen in 1897 by the British colonialists (Egharevba 58). His family history can be traced to the previous fourth generation beginning from Obanosa, to Iyasinhenmwen of Ugbague to Obayagbona of Lagos street and Igbinovia Obayagbona Noweko who was born in Lagos Street and later 
settled in Eyaen village as a farmer. Igbinovia's father died in 1957 while he was less than ten years old. Igbinovia was born fifty-two years after the British invaded and sacked Benin in 1897. He inherited his talent as a carver from his maternal grandfather, Ehiorobo, who hailed from Igumukua in Orhiomwon local government area, but later settled at Eyaen village where he became the Odionwere (village head). He was reputed to be an excellent carver. This was during the reign of Oba Ovonramwen who ascended the Benin throne in 1888. His prowess as a carver might have contributed to his appointment as Enogie of Eyaen by the Oba considering the fact that Benin Obas from the beginning of the establishment of the community have high regard and desire for quality art works which are used to decorate the palace, document history or presented to visiting monarchs or other important guests to the kingdom which led to the formation of the Iwebo society, the body in charge of the production of art works and management of artists in the kingdom, which Igbinovia was a member. According to Ikpakoroye, "Igbesanmwan no doubt must have produced some excellent unsung artists" (4). Observing Igbinovia, Ikpakoroye notes:

Art is in my blood, my life and my power. If I close my eyes, I see different art works. If I am looking at a wall, I see some designs. Anytime I sit down alone, I just see different art works. I have gone to the sea through vision and seen different art works, I have gone to the forests through vision and seen different art works. When I look at trees and the mace of leaves in them, what I see is design. (2)

His predisposition in this regard agrees with the belief in Benin that whatever a man or woman becomes on earth is determined in the world beyond before he is born. In other words, the talent that a man expresses on earth is invested in him by the gods. According to Ero, "It is believed that before a person goes to the earth, he kneels before his creator Osanobua and tells him what he wishes to be in the world whether a farmer or a trader, a warrior or a carver etc" (50). Considering the importance of the Iwebo society of the palace in the Benin kingdom as the producers of art works and fashion for the Oba, his maternal grandfather, Ehiorobo may have been a member of the Iwebo society in spite of the fact that the Iwebo society was basically resident in Igbesanmwan district of Benin City, about eight kilometers from Eyaen village where he resided.

This brings about the question of the source of Queen Idia mask, a mask that had not only occupied a central place in the cultural womb of Benin people, but also that of the black world. Thus, the origin of Queen Idia mask must have been located between the Iwebo society, which housed the carvers' guild in Igbesanmwan district and Ehiorobo, Igbinovia's maternal grandfather who was a reputed carver in the kingdom. The researchers have decided to canvass this view here because in spite the importance of the Queen Idia mask, there has not been serious attempt to consolidate its source or timing. This study therefore is of the view that it was a product of the palace Iwebo society/Igbesanmwan carvers. It is hoped that since the British have refused to return the Queen Idia mask to the country, they would avail the Africans through carbon dating the period the mask was produced to enable them situate history properly in time, knowing that Queen Idia, which the mask immortalizes lived till the first quarter of the 16th century and took part in the kingdom's war with the Atah of Idah, which took place between 1515 and 1516, and her gallantry in the war brought her to limelight (Egharevba 29). It, therefore, means that the original mask was produced sometimes after her death.

Igbinovia was brought up by his maternal grandparents when as a child his mother left his father and married another man. His education did not go beyond the primary school level because his mother who was responsible for his education could not afford the cost of training him further. He started his education in Eyaen village in 1956 
and at the death of his father in 1957, his mother relocated to Odiri and later to Ikoro village and Usen. The constant movement of his mother in search of better trading opportunities affected his education. He started primary school all over again at Baptist School, now Emokpae Primary School along Mission Road, Benin City between 1962 and 1963. He later moved to Cherubim and Seraphim School where he completed his primary education in 1966. Unable to proceed further with his education, in 1967, he was advised by a neighbor who was impressed with his skill in drawing to enroll as an apprentice in a carving workshop. His mother took him to Igbesanmwan district; the district of carvers and enrolled him as an apprentice in the workshop of Samson Okungbowa at Number 25 Igbesanmwan Street. According to Egharevba, "There were many improvements during the reign of Ere. He founded many villages such as Ego and Erua and groups of craftsmen known as Onwina and Igbesanmwan" (1). Igbinovia completed his training in 1969 at the age of eighteen, but not without interruptions from the Nigerian/Biafra civil war that was ongoing at that time.

\section{Joseph Alufa Igbinovia: Early Professional Practice}

At the completion of his training, Igbinovia went through the ritual of initiation into the Iwebo society to enable him practice the trade as a legal and recognized member of the traditional society, which holds the monopoly of carvings in the kingdom. Due to his expertise in the trade, he did not have any problem practicing at the highest level, which involved producing works within the palace. He notes: "There are many things or works that they did in the palace that they did not bring out" (Ikpakoroye 5). This statement justifies the fact that during the British attack on the palace, they were fascinated with the array of art work found in the palace that they carted many of them away as war booty including the esteemed Queen Idia mask. Oba Erediauwa, in his speech on the occasion of the launching of the Benin centenary in Calabar in 1996, observes: "Also, after I moved into the palace in 1979 and finding my way around, I stumbled on a delightful bronze object of my great ancestor, Oba Esigie, in European dress- a" photograph" (so to speak) of him on his return from Portugal in the 16th century" (Owie 14).

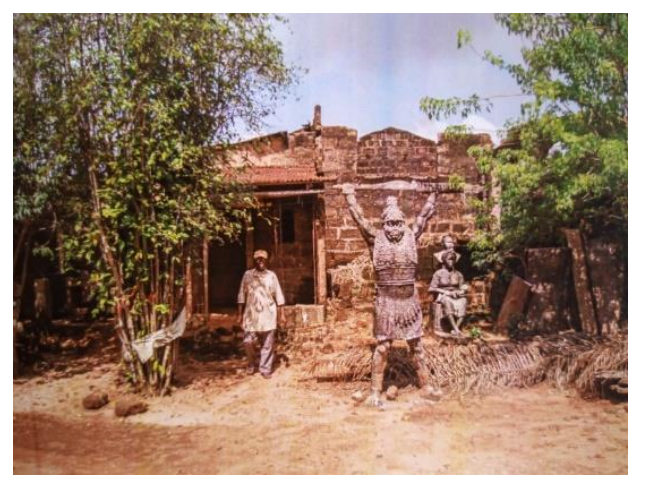

Fig. 1. Igbinovia's residence and workshop (Photo by NGA)

Igbinovia opened his first gallery along Sapele Road in conjunction with another colleague in 1969. One of his first major jobs was given to him by a manager at African Continental Bank (ACB). He was also patronized by Mr. Jarvis, a Briton who was the head of Nigerian Television Authority (NTA), Benin. At that time, he was lodging at Emotan Hotel along Sapele Road. He bought a wooden chest from Igbinovia for twelve pounds. According to Jonathan Ihonde, Mr. Jarvis was responsible for establishing the popular television show "Hotel De Jordan" on Nigerian Television Authority (NTA), Benin. Igbinovia used part of the sales to offset the balance of his apprenticeship fee and 
got his freedom. After a while, he closed up the shop due to lack of patronage and joined his master, Mr. Okungbowa. He later rented another shop along Evborhan Street after completing his graduation rites as an apprentice. It took some time for Mr. Jarvis to locate Igbinovia again and he requested for two bigger wooden chests for the sum of fifty pounds. With that money and proceeds from other minor jobs, Igbinovia bought a silver bicycle, which was a pride to have at that time in Benin City and married. His business was boosted with expanded patronage from the Germans, Britons and Americans that were working with some construction firms especially Gwatto at that time in Benin City (Ikpakoroye 6).

At the exit of his expatriate customers, Igbinovia joined a carvers' cooperative association known as Edaiken United Carving Industry along Mission Road. They were independent carvers with different workshops, but made use of a common showroom to exhibit and market their works. At some point, Benin became over saturated with carving industries and as patronage dwindled, he was compelled to relocate to Port Harcourt where he joined an old Benin Carver who had some Northerners and Rivers State Arts Council as his major patrons. His works were also exhibited for sale at the Festival of Arts and Culture held in Port Harcourt during that period. He later fell ill in Port Harcourt and auctioned his works before returning to Benin City for medical attention.

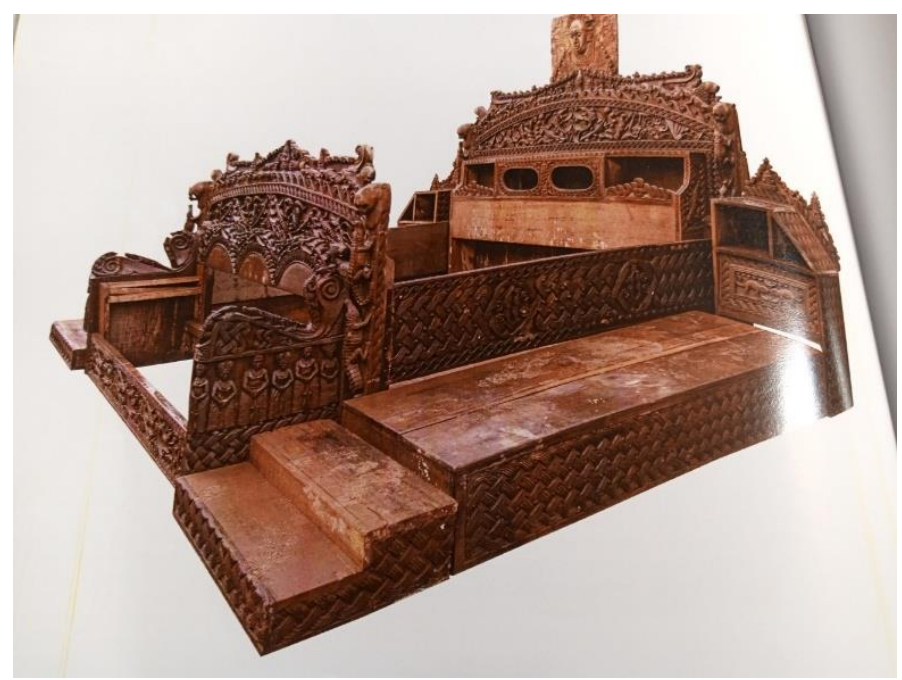

Fig. 2. Bed of life by Igbinovia (Photo by NGA)

\section{The Search for Festac Symbol}

It was while in Benin City receiving treatment that the Federal Government announced the plan to host FESTAC in 1977. A corresponding announcement was made by the then Bendel Arts Council inviting the artists to submit their works for exhibition in respect of the forthcoming festival of arts and culture (FESTAC) to be held in Lagos. He produced a new work entitled Olokun Obaramen, a seven feet high carving, which he submitted including an older work Imedumiran for the proposed exhibition. In view of the cultural significance of the festival to Africa and the black world, the Federal Government needed an art piece that would be used as a cultural/spiritual symbol of the black world for the celebration. The stolen Queen Idia mask fitted this need and the Federal Government requested the British Government to release the Queen Idia mask earlier removed from the palace of the Oba of Benin during the 1897 expedition, but the British Government requested a down payment of two million pounds' deposit as insurance. The Nigerian Government turned down this request because the amount was 
too exorbitant. Due to the strong need to get a replacement for the original mask, Igbinovia who had produced Olokun Obaramen that was regarded as a master piece was mandated to reproduce a replica of the original Queen Idia mask in ivory that would be used as the official symbol for FESTAC. With the aid of a photograph of the original one, he reproduced a replica, which was adjudged to be very good and was however requested to produce another one. The second one, an eight feet height mask, was adjudged better than the former.

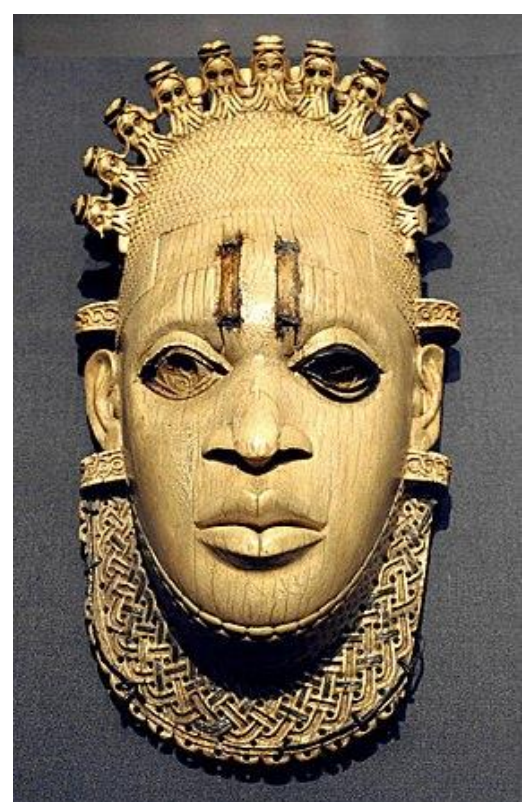

Fig. 3. Queen Idia mask (Original Sculptured by Igbinovia)

\section{The Concept of Idia Mask}

Carving and bronze casting are two major art forms in the Benin kingdom that are very functional as a means of historical documentation or representation of important personalities in the image forms. According to Erediauwa, what is commonly referred to as works of art today were not in the ancient Benin kingdom as these objects serve as records of events in the age when there was no photography or other forms of documentation (qtd. in Omoruyi 5). Carving and bronze casting are highly organized and regulated art forms in the kingdom. They come under the strict supervision and management of the Iwebo society in the palace with the Oba at the helm of the practice. Due to the need for continuity and expertise, these practices come under a central guild system of the Iwebo palace society under the headship of Ukoniwebo, which is equivalent to a chief. This is a special honour given to anyone that has meritoriously served the Oba in the capacity as the head of the group in charge of producing art materials and costumes for the Oba. This practice has been in existence for many centuries and it shows the importance attached to art and artistry in the kingdom. The Benins have used this method to document important historical events or to immortalize some personalities in the kingdom. Queen Idia was not the first important personality to have her face reproduced in carving, but she was the first and most notable till date whose motif in carvings has revolutionized this art form and brought the Benin carving to the world's attention. The Queen Idia mask apart from being used as a physical/spiritual symbol of FESTAC 77 is also the official logo of Independent Television, Benin City, a private broadcast outfit. 
Queen Idia was the wife of Oba Ozolua who ruled the Benin kingdom from 1483-1504 and the mother of Oba Esigie who also ruled the kingdom from 1504-1550 as a successor of Oba Ozolua, his father. In this case, Eweka states:

The first Iyoba (Queen mother) who lived at Uselu was Idia the mother of Oba Esigie. Queen Idia made her prowess from one of the many wars fought during the reign of her son Oba Esigie to consolidate the large empire established by her husband Oba Ozolua through the conquest of neighboring lands such as Iyekorhiomwon, Ogbelaka, Iguisi, Iwu, Utekon, Oka, Evbiakagba, Ishan, Amagba, Ovbierhe, Okeze, Olokhumwun, Ovbivbi, Iwu, Utekon, Owo, Origbo, etc. (32)

But for Egharevba, "He fought and won no less than two hundred battles which merited his agnomen Ozolua n' Ibaromi- Ozolua the conqueror" (23).

\section{Joseph Alufa Igbinovia: His works}

In spite of the fact that it was his work "the Festac mask" that brought him to the national and international limelight, considering a number of countries from the African continent, South America and the Caribbean that participated in the festival, Igbinovia was a man whose arts works had before this event attracted the attention of several foreigners that were working in Benin City and later Port Harcourt where he relocated. After the euphoria and excitement of FESTAC, he retired to his private practice until the then Bendel State Government offered him employment at Bendel Arts Council as a resident carver. He was the chief carver at the carver's workshop located inside the council from where they produced most of the art works that were exhibited for sale at the council's art shop located in the then new Nigerian Bank building beside the gate of the palace of the Oba of Benin. The shop attracted several important customers from other states and outside the country. At its height, it was a stopover point for visitors to the Oba's palace.

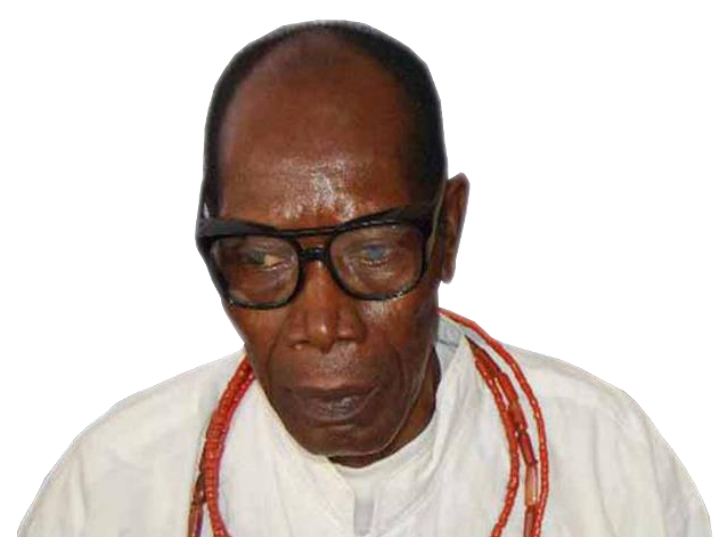

Fig. 4. Photo of Joseph Alufa Igbinovia

In his first few years of working at Bendel Arts Council craft workshop, Igbinovia was promoted, but after a while he became stagnated due to the policy of the council, which required him to provide further educational qualification before he could be promoted. After a while, he became disillusioned with the job and deserted to go back to the private practice once more and pursue his compensation by the Federal Government for his works Olokun Nobarame and the Queen Idia mask, which were collected by the Federal Government after the "Festac" festivity. It is sad to note that since the 1980s that he had embarked on legal processes to compel the Federal 
Government to compensate him for his works or return the same, there had been no positive response as he said:

I have spent most of my earnings from some major works I was commissioned to do by some important people in the country to pay lawyers to fight my case all to no avail. He further stated that "my case has now become like the case of the Federal Government and the British Government on the issue of repatriation or compensation for the arts works removed illegally from Benin kingdom. My works were taken from me without compensation. (Igbinovia)

Some of his major works, which are exhibited at various private homes and galleries include Mother and Child, Imedumiran, the greedy hunter, a full length sculptor of Chief Anthony Enahoro, Oba Ovoramwen, Igioromi, etc.; and the Hydra Headed monster, Asoro the Benin warrior, Emotan statue, the king of Umri and his dwarf, the Thunder, the Crucifix of Christ, the Unicorn, the Pot of Life, Royal bed and the Royal Throne, etc.

Some of the iconic works of Igbinovia that are worth special attention here are the Liberation Temple, which he constructed for his Royal Eminence, Ambassador Dr. Ramas Okoye Azuzu (FCON) of Nri kingdom and Umunri clan. Ezeoba, Akajiofor Ndigbo Gburugburu, Odenigbo 1 of Igboland (Ikpakoroye 54). It is an overwhelming work, adorning the entire space of the Universal Worship Centre, a center. All religions converge under the mighty power of the Almighty God. The images represented in this center are depictions of religious/spiritual essence of God and some are mounted on pedestal of about fifty feet tall.

One of his works worthy of note is the one commissioned by Obiekuniam, which was inspired from the Book of Revelation. Here, Ikpakoroye opines, "Obiekuniam went in to the book of Revelations that talk about the four living creatures that govern the four corners of the world" (101). Depicted on this work are the crucifix, the globe, the head of a lion, the Eagle, Mermaid, Holy Mary and a number of angels, bearing trumpets and inscribed on a pedestal, which holds the form is an extract from Psalm 23. Other notable clients that Igbinovia had produced the art works for include Oba Erediauwa, the 38th Oba of Benin kingdom, David Uyunmwun Edebiri, the Esogban of Benin kingdom, Chief Eduwuiofo Ekhator, the Obasogie of Benin kingdom and Ebohon Osemwengie.

\section{Conclusion}

The findings of the study show that Igbinovia is a spiritually motivated and informed artist. His art works go beyond mere representation of the physical; they also represent the spiritual world, which is the fountain of his inspiration. His intuition is endowed with a stealthy appreciation and association with the supernatural, which in an interview with him on 10 May 2020, he admits that he communes with the gods and they commune with him. In general, he appears like a man so "sinned against that he never sinned". Looking pensive and dejected, he noted that his condition is due to the fact that he had been miserably treated by a country he had served with his talent and youth. At seventy-one, he looked frail and sickly, but he is quick to tell the people not to be deceived by him that looks when it comes to doing his work, there is no mountain that he cannot climb, or river that he cannot cross. In front of his house is a small shrub, which he said is called "uwenrionta" in the Benin language. He said that it is a shrub that speaks and on two occasions it had spoken to him. He noted that on the first occasion, a young boy had come to his compound and messed up with his works. When he was told he rushed to the boy's house in the neighborhood only to be told that he was not at home. As he returned home angrily and passing the shrub, he heard the words "don't get angry, he is only a small boy." At first, the strange voice did not make any sense to him. He had walked a few steps away from the shrub when the implication of what he had heard 
dawned on him. He walked back and as he was gazing at it, he heard the words again distinct and clear "don't get angry, he is only a small boy."

\section{Works Cited}

Akpabot, S.E. "Musicological Approach to Efik/Ibibio Oral Poetry". Oral Poetry in Nigeria. Edited by U.C. Abalogu, G. Ashiwaju, and R. Amadi Tshiwala. Nigeria Magazine, 1981, p. 86.

Brockett, O.G. History of the Theatre. $9^{\text {th }}$ ed., Allyn and Bacon, 2003.

Ebohon, O. Olokun. Worship in Benin Kingdom. Ebohon Centre, 2010.

Egharevba, Jacob. A Short History of Benin. $4^{\text {th }}$ ed., Ibadan University Press, 1968.

Egharevba, Jacob. A Short History of Benin. $5^{\text {th }}$ ed., Fortune and Temperance, 2005.

Ero, O. Igue and other Festivals in Benin Kingdom. Osunero, 2003.

Eweka, E.A. The Benin Monarch-Origin and Development. n.p., 1989.

Igbinovia, Joseph Alufa. Interview. Conducted by Festus Osarumwense Uzzi, 10 May 2020.

Ikpakoroye, S. Festac 77-Unmasking the Unsung Hero. N.G.A, 2019.

Moore, G. Wole Soyinka. Evans, 1978.

Omoruyi, A. Benin Series-A New Dimension in Benin Studies. National Museum, 1982.

Osakue, O.S. and D.E. Omoruan. "The River Goddess and the Melody-Makers in Nigeria: A Cultural View on Majek Fashek and Victor Uwaifo." Modern Africa: Politics, History and Society, vol. 7, no. 2, 2019, pp. 31-54. https://:doi.org/10.26806/modar. v7i1.

Owie, S. P. Oba Ovonramwen N'ogbaisi in Calabar: The Untold Story. Achievers Global Resources, 2007.

\footnotetext{
To cite this article [MLA style]:

Omoruan, Daniel and Festus Osarumwense Uzzi. "God's Chisel in the Hands of the Carver: An Esoteric View of Joseph Alufa Igbinovia." SCHOLARS: Journal of Arts \& Humanities, vol. 4, no. 1, February 2022, pp. 44-52. NepJOL, doi:10.3126/sjah.v4i1.43054.
} 